\title{
Population structure of the expansive wasp spider (Argiope bruennichi) at the edge of its range
}

\author{
Wioletta Wawer ${ }^{1}$, Robert Rutkowski ${ }^{1}$, Henrik Krehenwinkel ${ }^{2,3}$, Dorota Lutyk ${ }^{4}$, Karolina Pusz-Bocheńska ${ }^{1}$ and Wiesław \\ Bogdanowicz': ${ }^{1}$ Museum and Institute of Zoology, Polish Academy of Sciences, Wilcza 64, 00-679 Warszawa, Poland. \\ E-mail: wawer@miiz.waw.pl; ${ }^{2}$ Department of Evolutionary Genetics, Max Planck Institute for Evolutionary Biology, \\ 24306 Plön, Germany; ${ }^{3}$ Department for Environmental Sciences, Policy and Management, University of California, \\ Berkeley, CA, USA; ${ }^{4}$ Institute of Environmental Sciences, Jagiellonian University, Gronostajowa 7, 30-387 Kraków, \\ Poland.
}

\begin{abstract}
The wasp spider Argiope bruennichi (Scopoli, 1772) is of Mediterranean-Pontian origin, but for decades it has been expanding northwards, including into the territory of Poland. Based on well-documented expansion records, we can distinguish "old" (south-eastern and south-western) and "new" populations (north-eastern), respectively, from the 1930s to the 2000s. In Poland, some populations of $A$. bruennichi were expected to be more genetically isolated from others, due to distance effects or differential times of arrival. We evaluated whether the oldest populations were in a state of HardyWeinberg equilibrium $(H W E)$, and whether recently founded populations were in an expansion phase. Specimens of $A$. bruennichi $(n=184)$ were collected at six localities in Poland and single sampling sites in Italy and Japan. Nine microsatellite loci were amplified although only five were useful in the final analyses. Based on the genotypes obtained, we estimated basic measures of genetic diversity and tested for deviation from $H W E$. The results showed a low level of polymorphism amongst the investigated markers, and accordingly, we found a low genetic diversity in populations. Only populations from Italy and Japan, and one population from Poland, were in $H W E$. The level of genetic differentiation among sampling sites from Poland was also very low. The high dispersal ability of the wasp spider appears to have facilitated high gene flow among populations. The peripheral and recently settled populations were characterized by the highest heterozygosity and the lowest inbreeding coefficient $\left(F_{\mathrm{IS}}\right)$. The remaining Polish populations are therefore still in the expansion phase, as indicated by deviations from $H W E$.
\end{abstract}

Keywords: Gene flow, dispersal, population structure, Araneae

The current distributions of species in Central Europe reflect the continent's glacial and post-glacial history, as well as the impacts of human activity on the environment. Habitat changes, such as a reversion to early successional stages and an increase in fallow areas, favor the migration and development of terrestrial arthropod populations. Habitat changes may inhibit range expansion, especially if the distances between patches are too large (Grez et al. 2004). However, in the case of organisms with high dispersal abilities, movement is still possible over long distances (Nee \& May 1992; Kareiva \& Wennergren 1995).

Spiderlings or even some adult spiders can spread through the air over large distances (sometimes even several thousand kilometers) by ballooning on lengths of silk (Gressitt 1965). This allows an unstable or newly accessible environment to be inhabited (Meijer 1977). Species with a high potential for dispersal generally display a homogeneous population structure, even over considerable distances (Slatkin 1993). In the case of orb-weaving spiders, whose dispersal capabilities are usually very high, a similarly high level of gene flow can often be observed among populations (Ramirez \& Fandino 1996; Ramirez \& Haakonsen 1999; Lee et al. 2004; Jung et al. 2006). Many studies have investigated genetic differentiation among populations of spiders (e.g., Ramirez \& Fandino 1996; Ramirez \& Haakonsen 1999; Lee et al. 2004; Jung et al. 2006; Croucher et al. 2011; Krehenwinkel et al. 2016b), but the balance between genetic drift and migration at the margins of a species' range is still poorly understood. Krehenwinkel \& Tautz (2013) and Krehenwinkel et al. (2015) examined the genetic variability in native and invasive populations of the "wasp spider" Argiope bruennichi (Scopoli, 1772), revealing marked distinctions between them. They aiso pointed to a significant role for genetic admixture, as reflected in a high genetic diversity in populations at the edges of the range.

Argiope bruennichi is of Mediterranean-Pontian origin, and its current range extends over the Palearctic region (Jäger 2012). During the past decades, populations of the wasp spider have been expanding northwards. In Poland, the first localities appeared in the west (1930s) and in the south-east (1960s), but this species was still rare until the 1990s (Urbański 1948; Barabasz \& Górz 1998). In the late 1990s, the number of localities at which the wasp spider increased considerably, and the species was soon present across the whole territory of Poland, except in the north-east where the climate is particularly harsh. Low temperature seems to matter most where the expansion of thermophilous species is concerned, and is considered as a limiting factor (Guttmann 1979; Kumschick et al. 2011) that probably explains the later arrival of A. bruennichi in the northern part of Europe (Jonsson 2004; Terhivuo et al. 2011). The rapid expansion in range may be the result of climatic warming, or else the local adaptation of the species to lower temperatures (Kumschick et al. 2011). Some studies have shown that an invasive population can exhibit increased cold tolerance, e.g., through the generation of an admixture of European and Asian lineages, the latter probably being pre-adapted for lower temperatures (Krehenwinkel \& Tautz 2013; Krehenwinkel et al. 2015, 2016a). It is nevertheless likely that, in such newly-colonized areas as the mountains of southern Poland or the north-east of Poland, populations of A. bruennichi will be vulnerable to severe temperature fluctuations to the point at which effective long-term colonization may be hindered. On the other hand, stable 


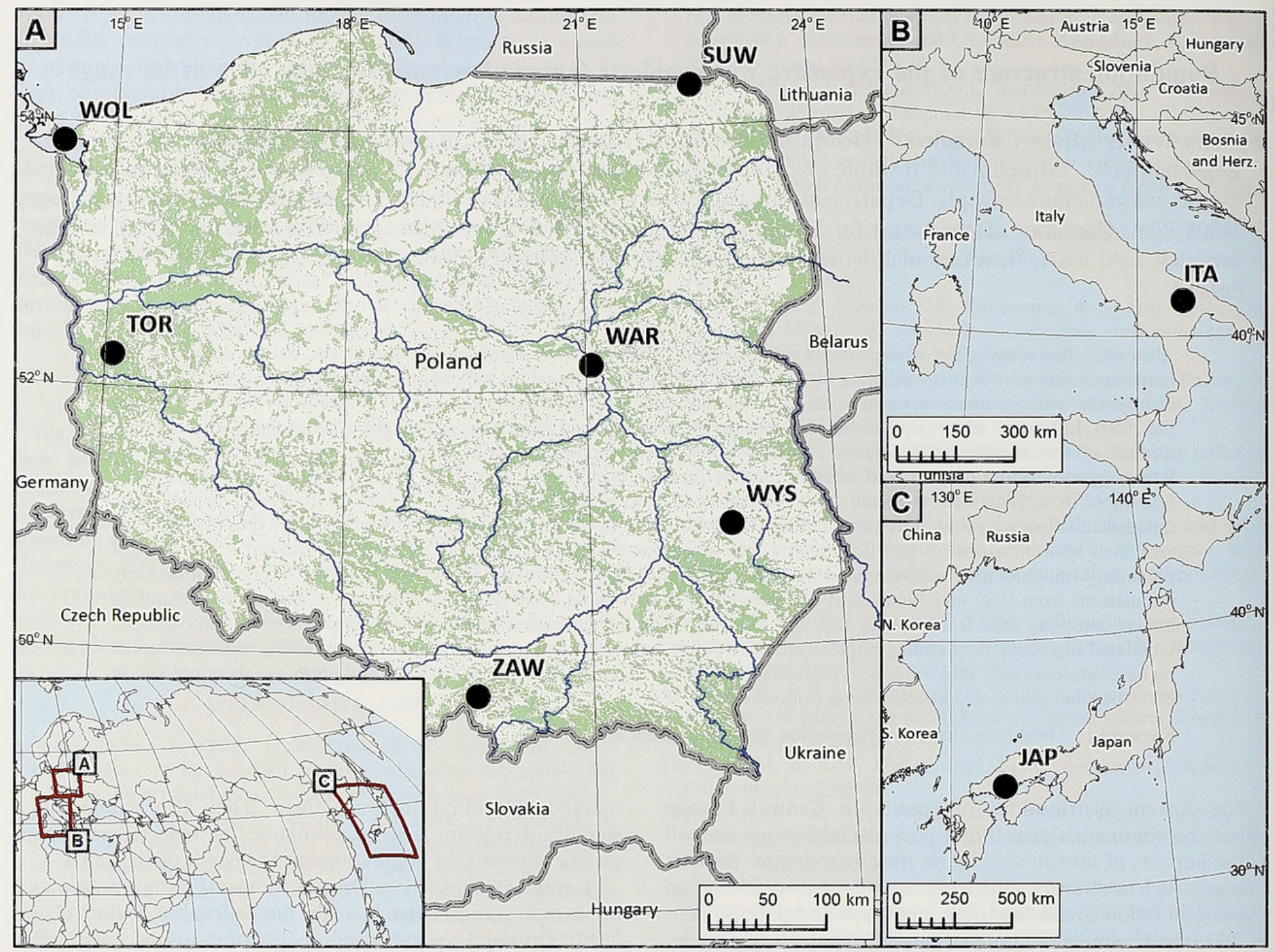

Figure 1.-Map showing the sampling locations.

populations can be expected to persist in the areas that were occupied first.

It is now recognized that genetic diversity decreases with increasing distance from the source population, and this is also true of invasive species (Ciosi et al. 2011; Kim \& Sappington 2013; Kononov et al. 2016). Populations at the limits of a species' range differ from those at the source in manifesting reduced levels of polymorphisms that reflect the overall loss of genetic variation. Likewise, at a finer geographic scale, the further from the center of the habitat, the lower the heterozygosity (Peter \& Slatkin 2013). Hardy-Weinberg disequilibrium has been observed in distinct locations for certain invasive species, across several generations (Zima et al. 2016). Moreover, edge populations can show low genetic variation when an investigated generation derives from just a few founder migrants (Bunn \& Hughes 1997). We therefore hypothesized that due to the small sizes and potentially ephemeral nature of founding populations, the genetic diversity of $A$. bruennichi would be lowest in north-eastern Poland, where the climate is harsh and the species only appeared recently. We in turn expect that the oldest populations - from the west and south-east of Poland - are in a state of Hardy-Weinberg equilibrium and present higher genetic diversity, while populations from the north-east of Poland remain in the expansion phase and are thus more likely to deviate from Hardy-Weinberg equilibrium.

\section{METHODS}

Study sites.-Specimens of A. bruennichi were collected from six localities in Poland (Fig. 1), taking into account the time of colonization and the presence of dispersal barriers (e.g., forests, rivers, mountains and human structures). These localities were: SUW (harsh climate conditions, youngest population, arrival ca. 2005 , at $54^{\circ} 18^{\prime} 50^{\prime \prime} \mathrm{N}, 22^{\circ} 27^{\prime} 18^{\prime \prime} \mathrm{E}$ ); TOR (mid-forest meadow habitat, oldest population, arrival ca. 1930 s, at $52^{\circ} 14^{\prime} 18^{\prime \prime} \mathrm{N}, 15^{\circ} 06^{\prime} 16^{\prime \prime} \mathrm{E}$ ); WAR (city habitat, at $52^{\circ} 11^{\prime} 30^{\prime \prime} \mathrm{N}, 21^{\circ} 04^{\prime} 07^{\prime \prime} \mathrm{E}$ ); WOL (island habitat, at $53^{\circ} 50^{\prime} 56^{\prime \prime} \mathrm{N}, 14^{\circ} 19^{\prime} 43^{\prime \prime} \mathrm{E}$ ); WYS (open area habitat without barriers, at $50^{\circ} 56^{\prime} 54^{\prime \prime} \mathrm{N}, 22^{\circ} 43^{\prime} 36^{\prime \prime} \mathrm{E}$ ); ZAW (mountain valley habitat, at $49^{\circ} 40^{\prime} 20^{\prime \prime} \mathrm{N}, 19^{\circ} 37^{\prime} 43^{\prime \prime} \mathrm{E}$ ). Additional samples came from "old" populations in Italy (1 locality, at $40^{\circ} 49^{\prime} \mathrm{N}$, $16^{\circ} 25^{\prime} \mathrm{E}$ ) and Japan (1 locality, at $\left.34^{\circ} 15^{\prime} \mathrm{N}, 132^{\circ} 34^{\prime} \mathrm{E}\right)$. We 
Table 1.- Characterization of microsatellite polymorphisms in eight populations $(n=184)$ of $A$. bruennichi. $n$ - sample size within population with successful amplification; $A-$ number of alleles; $R_{\mathrm{A}}$ - allelic richness; $R_{\mathrm{P}}$ - private allelic richness; $E_{\mathrm{A}}-$ effective number of alleles; $H_{\mathrm{O}}-$ heterozygosity observed; $H_{\mathrm{E}}-$ heterozygosity expected; $H W E-P$-values for HWE exact test for heterozygote deficiency/excess (those statistically significant are in bold); $F_{\text {IS }}$ - fixation index; $*$ statistically significant values of $F_{\text {IS }}$ and $P$-values for $H W E$ after Bonferroni correction ( 800 randomizations, adjusted $P$-value at $\alpha=0.05$ was 0.0013 ).

\begin{tabular}{|c|c|c|c|c|c|c|c|c|}
\hline Locus & A & $R_{\mathrm{A}}$ & $R_{\mathrm{P}}$ & $E_{\mathrm{A}}$ & $H_{\mathrm{O}}$ & $H_{\mathrm{E}}$ & $H W E$ & $F_{I S}$ \\
\hline & & & & & $(n=25$ & & & \\
\hline MA3 & 10 & 7.31 & 0.11 & 2.84 & 0.480 & 0.648 & $<0.05$ & 0.278 \\
\hline MA5 & 7 & 5.64 & 0.02 & 2.80 & 0.680 & 0.642 & 0.616 & -0.038 \\
\hline MA7 & 2 & 2.00 & 0.00 & 1.77 & 0.400 & 0.435 & 0.663 & 0.101 \\
\hline MA33 & 6 & 5.34 & 0.71 & 3.58 & 0.320 & 0.721 & $<0.001 *$ & $0.570 *$ \\
\hline \multirow[t]{2}{*}{ MA35 } & 3 & 2.81 & 0.03 & 1.44 & 0.360 & 0.306 & 1.000 & -0.155 \\
\hline & \multicolumn{8}{|c|}{ TOR $(n=25)$} \\
\hline MA3 & 8 & 7.00 & 0.13 & 4.48 & 0.320 & 0.777 & $<0.001 *$ & $0.601 *$ \\
\hline MA5 & 5 & 4.78 & 0.08 & 3.25 & 0.720 & 0.692 & 0.751 & -0.020 \\
\hline MA7 & 3 & 2.56 & 0.26 & 1.71 & 0.320 & 0.414 & 0.484 & 0.246 \\
\hline MA33 & 4 & 3.97 & 0.00 & 2.69 & 0.360 & 0.628 & $<0.01$ & 0.443 \\
\hline \multirow[t]{2}{*}{ MA35 } & 2 & 2.00 & 0.00 & 1.32 & 0.200 & 0.241 & 0.386 & 0.189 \\
\hline & \multicolumn{8}{|c|}{ WOL $(n=25)$} \\
\hline MA3 & 6 & 5.37 & 0.00 & 2.28 & 0.423 & 0.561 & $<0.05$ & 0.265 \\
\hline MA5 & 6 & 5.36 & 0.00 & 2.73 & 0.654 & 0.634 & 0.757 & -0.012 \\
\hline MA7 & 3 & 2.54 & 0.24 & 1.36 & 0.308 & 0.266 & 1.000 & -0.140 \\
\hline MA33 & 3 & 3.00 & 0.00 & 2.75 & 0.154 & 0.636 & $<0.001 *$ & $0.766^{*}$ \\
\hline \multirow[t]{2}{*}{ MA35 } & 2 & 2.00 & 0.00 & 1.30 & 0.269 & 0.233 & 1.000 & -0.136 \\
\hline & \multicolumn{8}{|c|}{ WYS $(n=25)$} \\
\hline MA3 & 10 & 7.76 & 0.57 & 4.58 & 0.640 & 0.782 & 0.126 & 0.201 \\
\hline MA5 & 8 & 6.87 & 0.07 & 4.11 & 0.600 & 0.757 & $<0.01$ & 0.227 \\
\hline MA7 & 3 & 2.56 & 0.56 & 1.76 & 0.520 & 0.431 & 0.730 & -0.186 \\
\hline MA33 & 5 & 4.78 & 0.15 & 2.98 & 0.240 & 0.665 & $<0.001$ & $0.651^{*}$ \\
\hline \multirow[t]{2}{*}{ MA35 } & 4 & 3.12 & 0.81 & 1.56 & 0.440 & 0.358 & 0.710 & -0.208 \\
\hline & \multicolumn{8}{|c|}{ SUW $(n=25)$} \\
\hline MA3 & 11 & 8.66 & 1.04 & 4.39 & 0.640 & 0.772 & $<0.05$ & 0.191 \\
\hline MA5 & 8 & 6.88 & 0.59 & 4.22 & 0.640 & 0.763 & 0.176 & 0.181 \\
\hline MA7 & 2 & 2.00 & 0.00 & 1.85 & 0.640 & 0.461 & 0.091 & -0.371 \\
\hline MA33 & 4 & 3.37 & 0.00 & 2.09 & 0.520 & 0.522 & 0.525 & 0.025 \\
\hline \multirow[t]{2}{*}{ MA35 } & 4 & 3.37 & 0.28 & 2.09 & 0.560 & 0.522 & 0.899 & -0.052 \\
\hline & \multicolumn{8}{|c|}{$\mathrm{ZAW}(n=25)$} \\
\hline MA3 & 9 & 7.52 & 0.42 & 4.03 & 0.800 & 0.752 & 0.978 & -0.043 \\
\hline MA5 & 6 & 5.10 & 0.05 & 2.58 & 0.600 & 0.613 & 0.230 & 0.041 \\
\hline MA7 & 2 & 2.00 & 0.00 & 1.27 & 0.160 & 0.211 & 0.287 & 0.262 \\
\hline MA33 & 3 & 3.00 & 0.00 & 2.68 & 0.200 & 0.626 & $<0.001 *$ & $0.692 *$ \\
\hline \multirow[t]{2}{*}{ MA35 } & 3 & 2.81 & 0.03 & 1.56 & 0.200 & 0.358 & $<0.05$ & 0.457 \\
\hline & \multicolumn{8}{|c|}{ ITA $(n=20)$} \\
\hline MA3 & 8 & 6.71 & 0.00 & 2.52 & 0.700 & 0.604 & 0.341 & -0.134 \\
\hline MA5 & 4 & 3.70 & 0.00 & 2.69 & 0.550 & 0.629 & 0.668 & 0.150 \\
\hline MA7 & 3 & 2.62 & 0.70 & 1.16 & 0.050 & 0.141 & $<0.05$ & $0.661 *$ \\
\hline MA33 & 2 & 2.00 & 0.00 & 2.00 & 0.550 & 0.499 & 1.000 & -0.077 \\
\hline \multirow[t]{2}{*}{ MA35 } & 2 & 2.00 & 0.00 & 1.92 & 0.300 & 0.480 & 0.153 & 0.397 \\
\hline & \multicolumn{8}{|c|}{$\operatorname{JAP}(n=14)$} \\
\hline MA3 & 4 & 4.00 & 0.15 & 2.97 & 0.357 & 0.663 & $<0.05$ & 0.490 \\
\hline MA5 & 4 & 4.00 & 0.09 & 2.35 & 0.357 & 0.574 & 0.066 & 0.409 \\
\hline MA7 & 3 & 3.00 & 1.00 & 1.81 & 0.357 & 0.446 & 0.316 & 0.235 \\
\hline MA33 & 4 & 4.00 & 1.00 & 1.46 & 0.357 & 0.314 & 1.000 & -0.102 \\
\hline MA35 & 6 & 6.00 & 4.00 & 3.73 & 0.643 & 0.732 & 0.125 & 0.158 \\
\hline
\end{tabular}


Table 2.-Mean allelic diversity and heterozygosity indices for five microsatellite loci in eight populations $(n=184)$ of $A$. bruennichi. $A-$ mean number of alleles; $R$ - allelic richness; $P_{\mathrm{A}}-$ private alleles; $R_{\mathrm{P}}$ - private allelic richness; $E_{\mathrm{A}}-$ effective number of alleles; $H_{\mathrm{O}}-$ heterozygosity observed; $H_{\mathrm{E}}$ - heterozygosity expected; $H W E-P$-values for $H W E$ exact test for heterozygote deficiency/excess; $F_{\mathrm{IS}}-$ fixation index; * - statistically significant values of $F_{\mathrm{IS}}$ and $P$-values for $H W E$ after Bonferroni correction ( 800 randomizations, adjusted $P$-value at $\alpha=$ 0.05 was 0.0013$)$.

\begin{tabular}{lccccccccc}
\hline Population & $A$ & $R$ & $P_{\mathrm{A}}$ & $R_{\mathrm{P}}$ & $E_{\mathrm{A}}$ & $H \mathrm{o}$ & $H_{\mathrm{E}}$ & $H W E$ \\
\hline WAR & 5.60 & 4.62 & 0.20 & 0.17 & 2.49 & 0.448 & 0.551 & $<0.001$ \\
TOR & 4.40 & 4.06 & 0.00 & 0.09 & 2.69 & 0.384 & 0.550 & $<0.001^{*}$ & 0.206 \\
WOL & 4.00 & 3.65 & 0.00 & 0.05 & 2.08 & 0.362 & 0.466 & $<0.001^{*}$ & $0.243^{*}$ \\
WYS & 6.00 & 5.02 & 0.24 & 0.43 & 3.00 & 0.488 & 0.599 & $<0.001$ & $0.204^{*}$ \\
SUW & 5.80 & 4.86 & 0.20 & 0.38 & 2.93 & 0.600 & 0.608 & 0.083 & 0.034 \\
ZAW & 4.60 & 4.09 & 0.00 & 0.10 & 2.42 & 0.392 & 0.512 & $<0.001^{*}$ & $0.254^{*}$ \\
ITA & 3.80 & 3.41 & 0.20 & 0.14 & 2.06 & 0.430 & 0.471 & 0.172 & 0.111 \\
JAP & 4.20 & 4.20 & 0.73 & 1.25 & 2.46 & 0.414 & 0.546 & 0.050 \\
\hline
\end{tabular}

collected the specimens in wastelands or meadows, as is typical for the species.

Sample collection.-We collected 184 specimens of $A$. bruennichi in July and August. In Poland, approximately 25 specimens were collected from each location, resulting in 150 specimens collected in 2012. Additionally, in 2013, we received specimens from Italy $(n=20)$ and Japan $(n=14)$. The collected material was stored in $95 \%$ ethanol at the Museum and Institute of Zoology (Polish Academy of Sciences), in Warsaw, Poland.

DNA extraction and amplification.-DNA extractions using a single leg from each spider were performed using the NucleoSpin ${ }^{\circledR}$ Tissue kit (Macherey-Nagel) according to the manufacturer's protocol. We aimed to amplify the following nine microsatellite loci in two multiplex reactions, as described by Krehenwinkel \& Tautz (2013): MA3, MA5, MA7, MA11, MA13, MA27, MA33, MA35 and MA57. Each forward primer was labelled with one of the following fluorescent dyes (WellRED Dyes): Dye2, Dye3 or Dye4. The reaction mixture contained: $1.5 \mu \mathrm{l}$ of the mixture of primers ("forward" and "reverse" for each locus, each primer at $2 \mathrm{pmol} / \mu \mathrm{l}) ; 7.5 \mu \mathrm{l}$ PCR Master Mix (QIAGEN); and $1 \mu$ of DNA extract. The reaction mix was then filled to $15 \mu \mathrm{l}$ with water for PCR (Sigma-Aldrich). The reactions were performed under the following conditions: $15 \mathrm{~min}$ at $95^{\circ} \mathrm{C}$; followed by 40 cycles of: $30 \mathrm{~s}$ at $94^{\circ} \mathrm{C}, 90 \mathrm{~s}$ at $57^{\circ} \mathrm{C}, 90 \mathrm{~s}$ at $72^{\circ} \mathrm{C}$; with a final $30 \mathrm{~s}$ at $94^{\circ} \mathrm{C}, 90 \mathrm{~s}$ at $57^{\circ} \mathrm{C}$, and $10 \mathrm{~min}$ at $72^{\circ} \mathrm{C}$. The genotyping analyses were performed using a $\mathrm{CEQ}^{\mathrm{TM}} 8000$ sequencer (Beckman Coulter).

Table 3.-Genetic differentiation among populations of $A$. bruennichi, estimated as $F_{\mathrm{ST}}$. $(*$ - statistically significant values after Bonferroni correction, 560 randomizations, adjusted $P$-value at $\alpha=$ 0.05 was 0.002$)$. The overall $F_{\mathrm{ST}}=0.058$ (95\% CI $\left.0.023-0.118\right)$.

\begin{tabular}{llllllll}
\hline Population & TOR & WOL & WYS & SUW & ZAW & ITA & JAP \\
\hline WAR & 0.010 & 0.005 & -0.003 & 0.022 & 0.007 & 0.041 & $0.182^{*}$ \\
TOR & & 0.024 & -0.010 & 0.020 & 0.008 & $0.063^{*}$ & $0.239^{*}$ \\
WOL & & & 0.024 & 0.049 & 0.002 & 0.033 & $0.252^{*}$ \\
WYS & & & & 0.002 & 0.004 & $0.042^{*}$ & $0.206^{*}$ \\
SUW & & & & & 0.030 & $0.031^{*}$ & $0.163^{*}$ \\
ZAW & & & & & & $0.023^{*}$ & $0.243^{*}$ \\
ITA & & & & & & & $0.238^{*}$ \\
\hline
\end{tabular}

Data analyses.-For each locus within each population, deviation from Hardy-Weinberg equilibrium (hereafter $H W E$ ) and linkage disequilibrium $(L D)$ was assessed using Fisher's exact test in Genepop version 4 (Raymond \& Rousset 1995; Rousset 2008), with the following settings: 10,000 dememorization steps, followed by 1,000 batches and 10,000 iterations. Basic genetic indices were calculated for each locus within each population as follows: (i) the number of alleles $(A)$; (ii) the allelic richness, or the number of alleles corrected for sample size using the rarefaction method with a sample of 14 individuals $\left(R_{\mathrm{A}}\right.$; Petit et al. 1998); (iii) the effective number of alleles $\left(E_{\mathrm{A}}\right)$; (iv) the number of private alleles $\left(R_{\mathrm{P}}\right)$; $(\mathrm{v})$ the observed $\left(H_{\mathrm{O}}\right)$ and expected heterozygosity $\left(H_{\mathrm{E}}\right)$ (Nei \& Roychoudhury 1974); and (vi) the inbreeding coefficient ( $\left.F_{\mathrm{IS}}\right)$. These analyses were performed using the programs GenAlEx (Paekall \& Smouse 2001), FSTAT version 2.9.3.2 (Goudet 2001), and HP-RARE (Kalinowski 2005). Moreover, for each population we estimated mean values of $A, R_{\mathrm{A}}, R_{\mathrm{P}}, H_{\mathrm{O}}, H_{\mathrm{E}}$ and $F_{\text {IS. }}$

Genetic differentiation among populations was assessed as $F_{\text {ST }}$ (Weir \& Cockerham 1984). Pairwise $F_{\mathrm{ST}}$ values and their significance, as well as overall $F_{\mathrm{ST}}$ with corresponding $95 \%$ confidence intervals were calculated in FSTAT.

The Bayesian-clustering method STRUCTURE version 2.3.4 (Pritchard et al. 2000) was used to examine how well the predefined "populations" corresponded to genetic groups $(K)$. STRUCTURE was run 10 times for each user-defined $K$, with an initial burn-in of 500,000, and 1,000,000 iterations of the total data set. The admixture model of ancestry and the correlated model of allele frequencies were used. Sampling location was not used as prior information. Next, we examined $\Delta K$ statistics to identify the largest change in the estimates of $K$ produced by STRUCTURE, as $\Delta K$ may provide a more realistic estimation of $K$ than those based on likelihood (Evanno et al. 2005). STRUCTURE was run for user defined values of $K=1-8$.

To obtain the $\Delta K$, we used STRUCTURE HARVESTER version 0.6.94 (Earl \& von Holdt 2011). We then applied CLUMPP version 1.1.2 (Jakobsson \& Rosenberg 2007) to average the multiple runs given by STRUCTURE and correct for label switching. The output from CLUMPP was visualized with DISTRUCT version 1.1 (Rosenberg 2004).

As the identification of genetic structure in STRUCTURE relies on $H W E$ optimization, and the majority of the sampling 


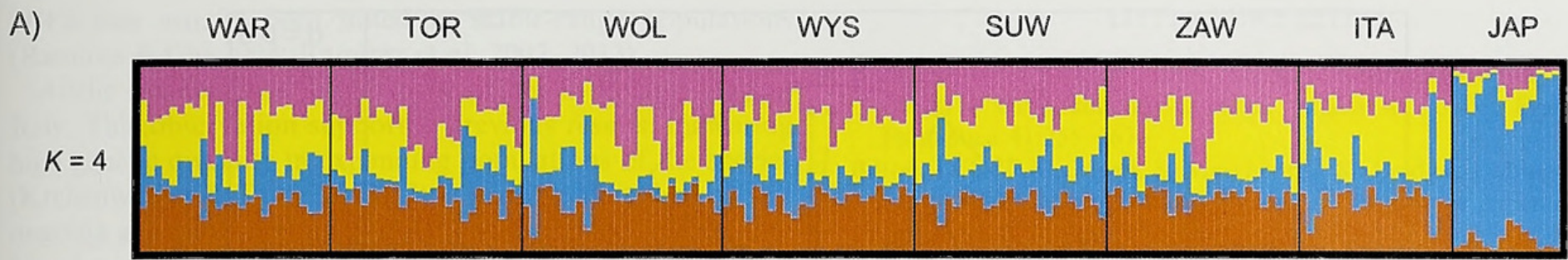

B)

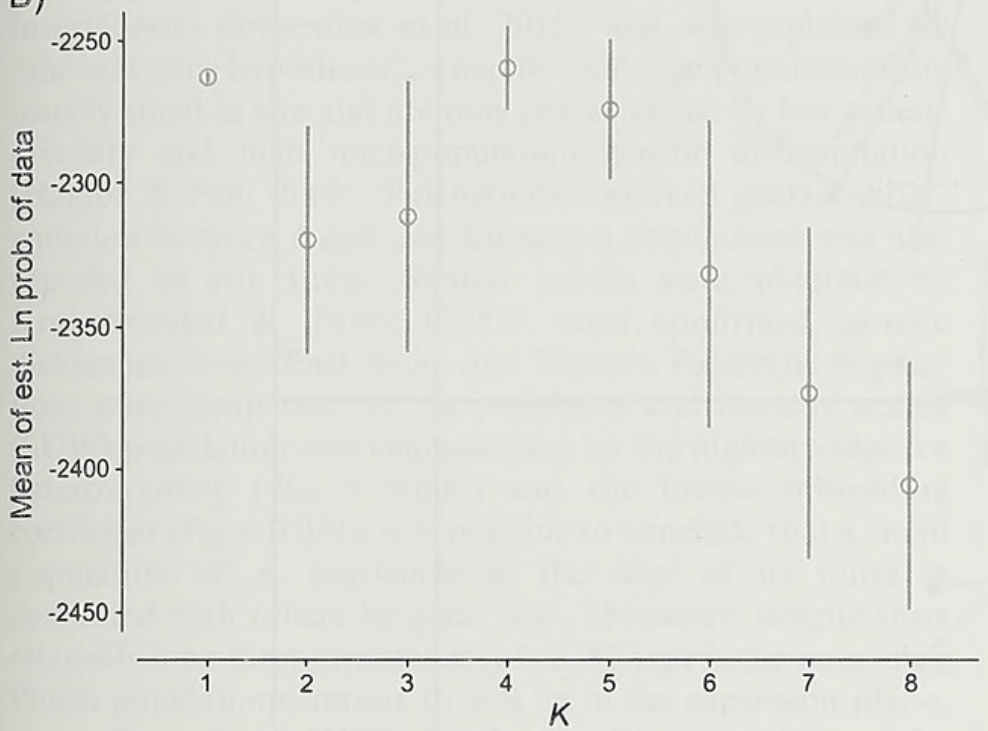

C)

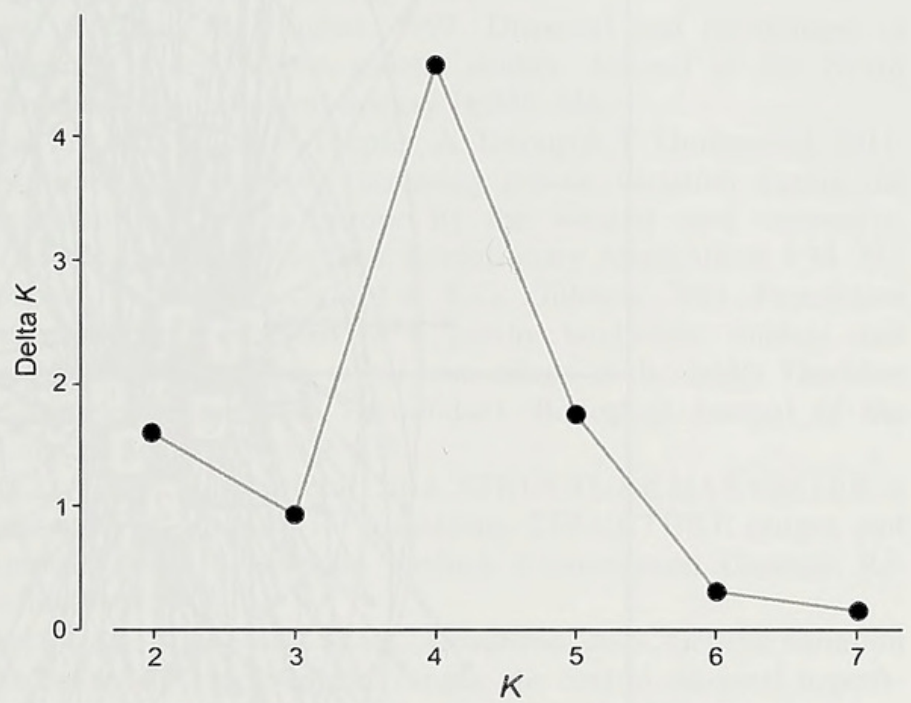

Figure 2.-Genetic structure in eight studied populations of A. bruennichi, inferred using STRUCTURE: A. bar plots for four genetic clusters; B. estimated mean (and SD) likelihoods; C. $\Delta K$ curves as a function of $K$. In bar plots each individual is represented by a vertical bar partitioned into segments. The length of each segment describes the estimated membership proportions to each of the genetic clusters. $\Delta K$ suggested the presence of four genetic clusters, however the mean likelihood was the highest and had the smallest variance for $K=1$.

sites in our study were not in $H W E$, we also obtained an additional representation of the genetic structure using principal component analysis (PCA). This multivariate descriptive method is not dependent on any model assumption and can thus provide a useful validation of the Bayesian clustering output (Patterson et al. 2006; McVean 2009; François \& Durand 2010). We used the R package ADEGENET version 1.3.4 (Jombart 2008) to carry out standard PCA. The results of the analysis were presented graphically along the first and second axes according to the highest Eigen values.

\section{RESULTS}

We failed to amplify the loci MA11 and MA13 in the majority of samples from Poland. Locus MA27 was monomorphic, while MA57 failed to amplify in samples from Italy. Hence, final analyses were performed for five microsatellite loci, i.e., MA3, MA5, MA7, MA33 and MA35.

The most polymorphic locus at the population level was MA3 ( $A$ ranging from 6 to 11 alleles, $R$ from 5.4-8.7), except for the JAP population, where MA35 had the highest number of alleles $(A=6)$. In the remaining loci, we observed rather low levels of polymorphism, usually from 2 to 5 alleles (Table 1). There was no significant linkage disequilibrium $(L D)$ among loci within populations (1,600 permutations, adjusted $P$-value after Bonferroni correction: 0.006). In the majority of populations, two out of five loci were not in $H W E$ (Table
1). Exceptions were populations SUW and ITA, for which only one locus exhibited a deviation from $H W E$. In all cases, significant deviation from $H W E$ was due to heterozygote deficiency. The inbreeding coefficient $\left(F_{\mathrm{IS}}\right)$ was significant for locus MA33 in five of the eight investigated populations. Other than MA33, a significant $F_{\text {IS }}$ was also found at locus MA3 in TOR, and MA7 in ITA (Table 1). In general, the observed heterozygosity was greatest at loci MA3 and MA5 in populations from Poland and ITA, while in JAP the highest $H_{\mathrm{O}}$ was found at locus MA35 (Table 1 ).

For mean indicators of genetic diversity (Table 2), populations could be divided into a first group with $A$ around 6.0 and $R>4.60$ (WAR, WYS, SUW), and a second group consisting of all remaining populations $(A<4.60 ; R<4.09)$. In general, allelic diversity and allelic richness were greater in populations from Poland, as opposed to Italy or Japan (Table 2). A similar pattern was observed for $H_{\mathrm{O}}$. However, the highest mean number of private alleles $\left(P_{\mathrm{A}}\right)$ and the greatest value for private allelic richness $\left(R_{\mathrm{P}}\right)$ were observed in the case of JAP.

Five out of eight investigated populations were not in $H W E$; in four of these $F_{\mathrm{IS}}$ was found to be significantly higher than zero (Table 2). Only one population from Poland (SUW), seemed to be in $H W E$, along with ITA and JAP.

Genetic differentiation $\left(F_{\mathrm{ST}}\right)$ was very limited and nonsignificant among the populations from Poland (Table 3 ). We found small but significant $F_{\mathrm{ST}}$ values in pairwise comparisons 


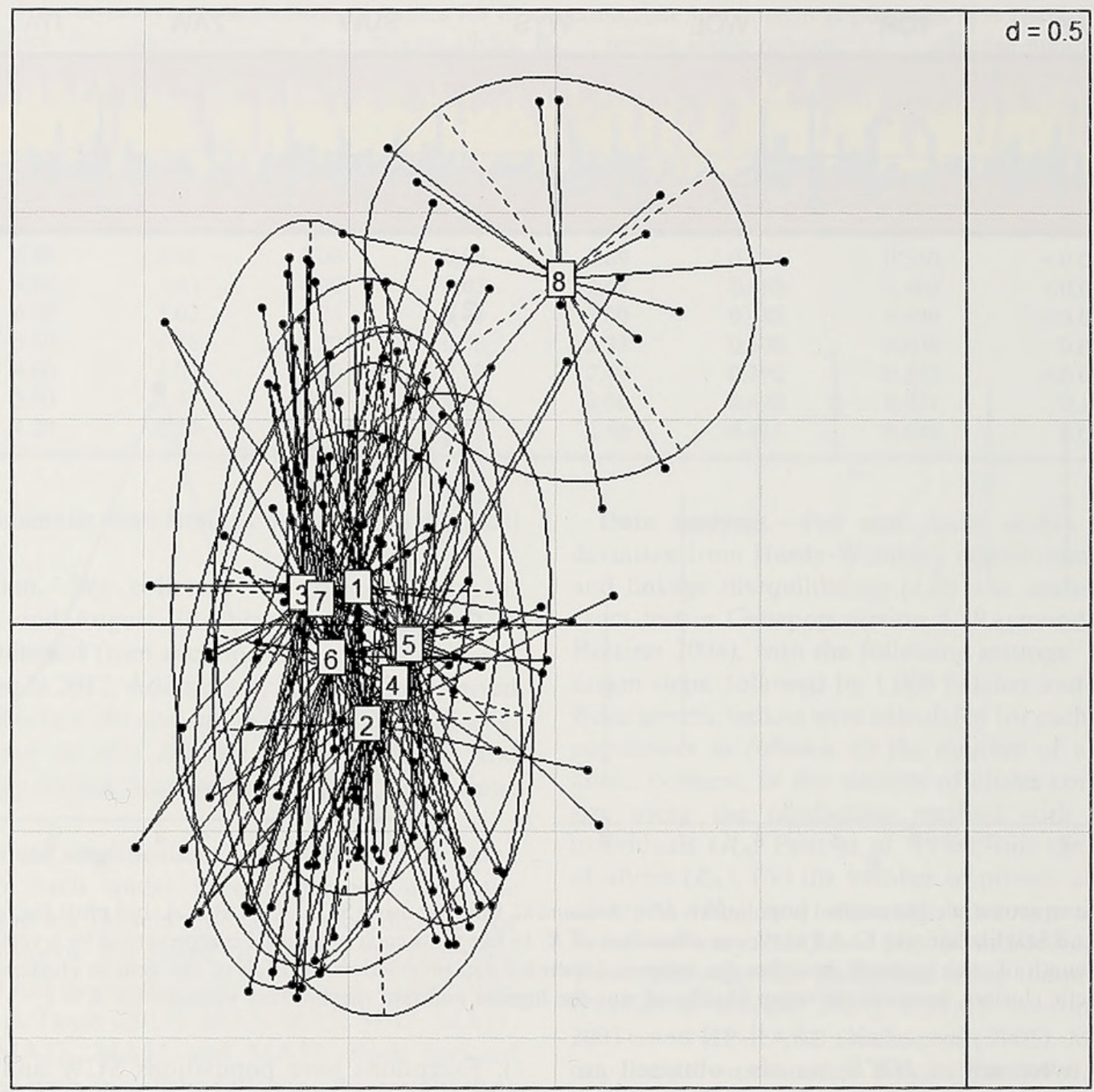

Figure 3.-Principal Component Analysis of A. bruennichi genotypes in eight examined populations. The results are presented along the first and second axes according to the highest eigenvalues. 1 -WAR; 2 - TOR; 3 -WOL; 4 -WYS; 5 - SUW; 6 - ZAW; 7 - ITA; 8 - JAP.

between populations from Poland and Italy. Genetic differentiation between JAP and the remaining populations was high and significant (Table 3).

Results from STRUCTURE analyses indicated the highest mean likelihood for $K=1$ and low variance among iterations, however a high likelihood was also found for $K=4$ (Fig. 2A, $B)$. Individuals from Poland and Italy were not assigned to a particular cluster, but rather had a mixed probability of ancestry from four genetic groups. The population from Japan consisted of individuals from a single cluster. The $\Delta K$ supported division of the observed genetic variability into four genetic clusters (Fig. 2C), and PCA analysis in turn suggested a division of populations into two genetic groups (Fig. 3), of which the first consisted of the populations from Poland and Italy and the second (mainly) of samples from Japan.

\section{DISCUSSION}

Our study indicated that genetic differentiation among populations of $A$. bruennichi in Poland was very low. Counter to our expectations, we infer that the strong dispersal abilities of this species ensure intensive gene flow, resulting in homogeneity of all the Polish populations, which are probably still undergoing range expansion. Similar results have been obtained for other populations of orb-weaving spiders (Ramirez \& Fandino 1996; Ramirez \& Haakonsen 1999; Lee et al. 2004; Jung et al. 2006), and indeed strong gene flow is frequently observed between populations of species with high dispersal abilities (Waples 1987; Bohonak 1999). However, significant genetic differences for species with high dispersal abilities have also been recorded (Sielezniew \& Rutkowski 2012; Lemic et al. 2013; Pentek-Zakar 2015).

According to Vucetich \& Waite (2003), populations at the edge of a species' range are generally smaller than those at the core, and observations for $A$. bruennichi suggest that the north-eastern (SUW) population is indeed smaller than others (e.g., 0.2 ind. $/ \mathrm{m}^{2}$ in SUW and 1.75 ind. $/ \mathrm{m}^{2}$ in HOR) (W. Wawer, unpubl. data). However, neither the new (SUW) nor the old (e.g., WYS and WOL) populations are in $H W E$ (Table 1). In fact, due to a heterozygote deficiency, many populations of expansive species are not found to indicate $H W E$, e.g., among Lepidoptera (Wei et al. 2013), Coleoptera (Wu et al. 2016) and Diptera (Yan et al. 2015). In the case of spiders, 
$H W E$ has usually been noted in stable-range populations (Ramirez \& Chi 2004; Ramirez et al. 2007, 2013).

Allelic richness was found to be higher in Poland than in Italy. This observation supported previous results, indicating high genetic diversity in expanding populations of the species (Krehenwinkel \& Tautz 2013). It is possible that there is still ongoing gene flow among populations in Poland, eliminating founder effects and isolation in newly colonized areas (Greenbaum et al. 2014). Higher genetic diversity in Poland as compared to Italy has also been recorded in other invertebrates (Sielezniew et al. 2015), and was explained by "the rear edge hypothesis", whereby rear edge populations are usually small in size and are thus characterized by low genetic diversity and high inter-population genetic differentiation (Hampe \& Petit 2005). Furthermore, marked genetic differentiation between Asian and European populations was also revealed in our study. Similar results were obtained by Krehenwinkel \& Tautz (2013), who confirmed genetic distinctness when East Asian and Western Palearctic populations were compared. As the peripheral and recently settled (SUW) population was characterized by the highest value for heterozygosity $\left(H_{\mathrm{O}}=0.600\right)$ and the lowest inbreeding coefficient $\left(F_{\mathrm{IS}}=0.034\right)$, it is possible to conclude that a small population of $A$. bruennichi at the edge of its range is connected with others by gene flow. Moreover, despite their relatively long-term persistence (of ca. 80 years), the remaining Polish populations appear to still be in the expansion phase, given the lack of $H W E$. Similar results were obtained by Wellenreuther et al. (2011) for populations of the highly vagile blue-tailed damselfly, Ischnura elegans (Vander Linden, 1820). Generally, populations displaying a high expansion rate are associated by gene flow, such that even long distances or geographical barriers do not inhibit the process (Wellenreuther et al. 2011). And although genetic diversity is greater far from the center, in most cases distant populations are seen to be similar genetically (Eckert et al. 2008)

At this stage of the research, we cannot confirm the hypothesis of a colonization of Polish territory from both the east and west (Urbański 1948; Barabasz \& Górz 1998). Analyses of genetic structure indicated similarity between the Polish and Italian populations, and while the Alps are known to have acted as an initial barrier to the possible northward expansion of Mediterranean genetic pools (Bilton et al. 1998; Hewitt 1999), the Appenine Peninsula might be a possible source area of invertebrate populations in Central and Northern Europe (Patricelli et al. 2013). This observation supports previous results obtained by Krehenwinkel \& Tautz (2013), suggesting that northern territories of Europe were colonized from southern localities rather than from eastern areas.

\section{ACKNOWLEDGMENTS}

We are grateful to our colleagues, Dr. Pamela Loverre (University of Bari Aldo Moro, Italy) and Dr. Yoshiko Honda (Fumakilla Limited, Japan) for collection the specimens of the wasp spider. We also thank two anonymous reviewers for their valuable comments and suggestions. The study was supported by the Polish National Science Centre (NCN), grant no. 2012 05/N/NZ8/02105.

\section{LITERATURE CITED}

Barabasz, B. \& A. Górz. 1998. Argiope bruennichi (Scopoli, 1772) rzadki i słabo zbadany gatunek pająka w Polsce. Fragmenta Faunistica 41:255-267.

Bilton, D.T., P.M. Mirol, S. Mascheretti, K. Fredga, J. Zima \& J.B Searle. 1998. Mediterranean Europe as an area of endemism for small mammals rather than a source for northwards postglacial colonization. Proceedings of the Royal Society of London Series B 265:1219-1226.

Bohonak, A.J. 1999. Dispersal, gene flow and population structure Quarterly Review of Biology 74:21 45

Bunn, S.E. \& J.M. Hughes. 1997. Dispersal and recruitment in streams: evidence from genetic studies. Journal of the North American Benthological Society 16:338-346.

Ciosi, M., N.J. Miller, S. Toepfer, A. Estoup \& T. Guillemaud. 2011 Stratified dispersal and increasing genetic variation during the invasion of Central Europe by the western corn rootworm, Diabrotica virgifera virgifera. Evolutionary Applications 4:54-70.

Croucher, P.J.P., G.S. Oxford \& R.G. Gillespie. 2011. Population structure and dispersal in a patchy landscape: nuclear and mitochondrial markers reveal area effects in the spider Theridion californicum (Araneae: Theridiidae). Biological Journal of the Linnean Society 104:600-620.

Earl, D.A. \& B.M. von Holdt. 2011. STRUCTURE HARVESTER: a website and program for visualizing STRUCTURE output and implementing the Evanno method. Conservation Genetics Resources 4:359-361.

Eckert, C.G., K.E. Samis \& S.C. Lougheed. 2008. Genetic variation across species' geographical ranges: the central-marginal hypothesis and beyond. Molecular Ecology 17:1170-1188

Evanno, G., S. Regnaut \& J. Goudet. 2005. Detecting the number of clusters of individuals using the software STRUCTURE: a simulation study. Molecular Ecology 14:2611-2620.

François, O. \& E. Durand. 2010. Spatially explicit Bayesian clustering models in population genetics. Molecular Ecology Resources 10:773-784.

Goudet, J. 2001. FSTAT V2.9.3, a program to estimate and test gene diversities and fixation indices. (Updated from: Goudet, J. 1995. FSTAT V1.2: a computer program to calculate F-statistics. Journal of Heredity 86: 485 486.) Online at https://www2.unil ch/popgen/softwares/fstat.htm

Greenbaum, G., A.R. Templeton, Y. Zarmi \& S. Bar-David. 2014 Allelic richness following population founding events - a stochastic modeling framework incorporating gene flow and genetic drift PLoS ONE 9(12):e115203. doi:10.1371/journal.pone.0115203.

Gressitt, J.L. 1965. Biogeography and ecology of land arthropods of Antarctica. Pp. 431-490. In Biology and Ecology of Antarctica. (J. van Miegham, P. van Oye, eds). Monographiae Biologicae 15.

Grez, A., T. Zaviezo, L. Tischendorf \& L. Fahrig. 2004. A transient, positive effect of habitat fragmentation on insect population densities. Oecologia 141:444 451.

Guttmann, R. 1979. Zur Arealentwicklung und Ökologie der Wespenspinne (Argiope bruennichi) in der Bundesrepublik Deutschland und den angrenzenden Ländern. Bonner zoologische Beiträge 30:454 486 .

Hampe, A. \& R.J. Petit. 2005. Conserving biodiversity under climate change: The rear edge matters. Ecology Letters 8:461- 467.

Hewitt, G.M. 1999. Post-glacial re-colonization of European biota. Biological Journal of the Linnean Society 68:87-112.

Jakobsson, M. \& N.A. Rosenberg. 2007. CLUMPP: a cluster matching and permutation program for dealing with labe switching and multimodality in analysis of population structure Bioinformatics 23:1801-1806.

Jäger, P. 2012. A review on the spider genus Argiope Audouin, 1826 with special emphasis on broken emboli in female epigynes 
(Araneae: Araneidae: Argiopinae). Beiträge zur Araneologie 7:272-331

Jombart, T. 2008. Adegenet: a R package for the multivariate analysis of genetic markers. Bioinformatics 24:1403-1405.

Jonsson, L.J. 2004. Getingspindeln, Argiope bruennichi, etablerad och sprider sig norrut i Sverige. Entomologisk Tidskrift 125:117-120.

Jung, J., J.-W. Lee, J.-P. Kim \& W. Kim. 2006. Genetic variations of the golden orb-web spider Nephila clavata (Araneae: Tetragnathidae) in Korea, using AFLP markers. Korean Journal of Genetics 28:325-332.

Kalinowski, S.T. 2005. A computer program for performing rarefaction on measures of alleli diversity. Molecular Ecology Notes 5:187-189.

Kareiva, P. \& U. Wennergren. 1995. Connecting landscape patterns and population processes. Nature 373:299-302.

Kim, K.S. \& T.W. Sappington. 2013. Population genetics strategies to characterize long-distance dispersal of insects. Journal of AsiaPacific Entomology 16:87-97.

Kononov, A., K. Ustyantsev, B. Wang, V.C. Mastro, V. Fet, A. Blinov et al. 2016. Genetic diversity among eight Dendrolimus species in Eurasia (Lepidoptera: Lasiocampidae) inferred from mitochondrial COI and COII, and nuclear ITS2 markers. BMC Genetics 17 (Suppl. 3):157.

Krehenwinkel, H. \& D. Tautz. 2013. Northern range expansion of European populations of the wasp spider Argiope bruennichi is associated with global warming-correlated genetic admixture and population-specific temperature adaptations. Molecular Ecology 22:2232-2248

Krehenwinkel, H., M. Graze, D. Rodder, K. Tanaka, Y.G. Baba, C. Muster et al. 2016a. A phylogeographical survey of a highly dispersive spider reveals eastern Asia as a major glacial refugium for Palaearctic fauna. Journal of Biogeography 43:1583-1594.

Krehenwinkel, H., D. Rödder, M. Năpăruş-Aljančič \& M. Kuntner. 2016b. Rapid genetic and ecological differentiation during the northern range expansion of the venomous yellow sac spider Cheiracanthium punctorium in Europe. Evolutionary Applications. doi:10.1111/eva.12392

Krehenwinkel, H., D. Roedder \& D. Tautz. 2015. Eco-genomic analysis of the poleward range expansion of the wasp spider Argiope bruennichi shows rapid adaptation and genomic admixture. Global Change Biology 21:4320 4332.

Kumschick, S., S. Fronzek, M.H. Entling \& W. Nentwig. 2011. Rapid spread of the wasp spider Argiope bruennichi across Europe: a consequence of climate change? Climatic Change 109:319-329.

Lee, J.-W., L. Jiang, Y.-C. Su \& I. Tso. 2004. Is central mountain range a barrier to giant wood spider Nephila pilipes? A population genetic approach. Zoological Studies 43:112-122.

Lemic, D., K.M. Mikac \& R. Bazok. 2013. Historical and contemporary population genetics of the invasive western corn rootworm (Coleoptera: Chrysomelidae) in Croatia. Environmental Entomology 42:811-819.

McVean, G. 2009. A genealogical interpretation of principal components analysis. PLoS Genetics 5:e1000686.

Meijer, J. 1977. The immigration of spiders (Araneida) into a new polder. Ecological Entomology 2:81-90.

Nee, S. \& R.M. May. 1992. Dynamics of metapopulations - habitat destruction and competitive coexistence. Journal of Animal Ecology 61:37-40.

Nei, M. \& A.K. Roychoudhury. 1974. Sampling variances of heterozygosity and genetic distance. Genetics 76:379-390.

Peakall, R. \& P.E. Smouse. 2001. GENALEX 6: Genetic Analysis in Excel. Population genetic software for teaching and research. Molecular Ecology Resources 6: 288-295. Online at http:/ onlinelibrary.wiley.com/doi/10.1111/j.1471-8286.2005.01155.x/full

Patterson, N., A.L. Price \& D. Reich. 2006. Population structure and eigenanalysis. PLoS Genetics 2:e190.
Patricelli, D., M. Sielezniew, D. Ponikwicka-Tyszko, M. Ratkiewicz, S. Bonelli, F. Barbero et al. 2013. Contrasting genetic structure of rear edge and continuous range populations of a parasitic butterfly infected by Wolbachia. BMC Evolutionary Biology 13:14. Online at http://www.biomedcentral.com/1471-2148/13/14

Pentek-Zakar, E., A. Oleksa, T. Borowik \& S. Kusza. 2015. Population structure of honey bees in the Carpathian Basin (Hungary) confirms introgression from surrounding subspecies. Ecology and Evolution 5:5456-5467.

Peter, B.M. \& M. Slatkin. 2013. Detecting range expansions from genetic data. Evolution 67:3274-3289.

Petit, R.J., A. El Mousadik \& O. Pons. 1998. Identifying populations for conservation on the basis of genetic markers. Conservation Biology 12:844 855 .

Pritchard, J.K., M. Stephens \& P. Donnelly. 2000. Inference of population structure using multilocus genotype data. Genetics 155:945-959.

Ramirez, M.G. \& B. Chi. 2004. Cryptic speciation, genetic diversity and gene flow in the California turret spider Atypoides riversi (Araneae : Antrodiaetidae). Biological Journal of the Linnean Society $82: 27-37$.

Ramirez, M.G. \& L.B. Fandino. 1996. Genetic variability and gene flow in Metepeira ventura (Araneae, Araneidae). Journal of Arachnology 24:1-8.

Ramirez, M.G. \& K.E. Haakonsen. 1999. Gene flow among habitat patches on a fragmented landscape in the spider Argiope trifasciata (Araneae: Araneidae). Heredity 83:580-585.

Ramirez, M.G., S.S. Eiman, M.M. Wetkowski, M.K. Mooers, M.H. Alvarez, K.G. Mitchell et al. 2007. Heterozygosity and fitness in a California population of the labyrinth spider Metepeira ventura (Araneae, Araneidae). Invertebrate Biology 126:67-73.

Ramirez, M.J., A.M. Ravelo \& L. Lopardo. 2013. A simple device to collect, store and study samples of two-dimensional spider webs. Zootaxa 3750:189-192.

Raymond, M. \& F. Rousset. 1995. GENEPOP (version 1.2): population genetics software for exact tests and ecumenicism. Journal of Heredity 86:248-249.

Rosenberg, N.A. 2004. DISTRUCT, a program for the graphical display of population structure. Molecular Ecology Notes 4:137 138.

Rousset, F. 2008. Genepop'007: a complete reimplementation of the Genepop software for Windows and Linux. Molecular Ecology Resources 8:103-106.

Sielezniew, M. \& R. Rutkowski. 2012. Population isolation rather than ecological variation explains the genetic structure of endangered myrmecophilous butterfly Phengaris (=Maculinea) arion. Journal of Insect Conservation 16:39-50.

Sielezniew, M., D. Patricelli, R. Rutkowski, M. Witek, S. Bonelli \& M.M. Buś. 2015. Population genetics of the endangered obligatorily myrmecophilous butterfly Phengaris (=Maculinea) arion in two areas of its European range. Insect Conservation and Diversity 8:505-516.

Slatkin, M. 1993. Isolation by distance in equilibrium and nonequilibrium populations. Evolution 47:264 279.

Terhivuo, J., N.R. Fritzén, S. Koponen \& T. Pajunen. 2011. Increased number of observations and notes of offspring production in the invasive orb-web spider Argiope bruennichi (Scopoli, 1772) (Araneae; Araneidae) in Finland. Memoranda Societatis pro Fauna et Flora Fennica 87:95-101.

Urbański, J. 1948. Argyope bruennichi (SCOPOLI) 1772 na wyspie Wolin oraz rozmieszczenie tego gatunku na ziemiach polskich (Arachn., Aran. Argyopidae). Badania Fizjograficzne nad Polską Zachodnią 1:160-169.

Vucetich, J.A. \& T.A. Waite. 2003. Spatial patterns of demography and genetic processes across the species' range: Null hypotheses for landscape conservation genetics. Conservation Genetics 4:639-645. 
Waples, R.S. 1987. A multispecies approach to the analysis of gene flow in marine shore fishes. Evolution 41:385-400.

Wei, S.-J., B.-C. Shi, Y.-J. Gong, G.-H. Jin, X.-X. Chen \& X.-F. Meng. 2013. Genetic structure and demographic history revea! migration of the diamondback moth Plutella xylostella (Lepidoptera: Plutellidae) from the southern to northern regions of China. PLoS ONE 8: e59654.

Weir, B.S. \& C.C. Cockerham. 1984. Estimating $F$-statistics for the analysis of population structure. Evolution 38:1358-1370.

Wellenreuther, M., R.A. Sánchez-Guillén, A. Cordero-Rivera, E.I. Svensson \& B. Hansson. 2011. Environmental and climatic determinants of molecular diversity and genetic population structure in a coenagrionid damselfly. PLoS ONE 6(6):e20440. doi:10.1371/journal.pone.0020440.

Wu, Y., F. Li, Z. Li, V. Stejskal, Z. Kučerová, G. Opit et al. 2016.
Microsatellite markers for Cryptolestes ferrugineus (Coleoptera: Laemophloeidae) and other Cryptolestes species. Bulletin of Entomological Research 106:154-160.

Yan, W., L. Liu, S. Huang, C. Li, Z. Ma \& W. Qin. 2015. Development and characterization of microsatellite markers for the fruit fly, Bactrocera tau (Diptera: Tephritidae). Applied Entomology and Zoology 50:545-548.

Zima, J., O. Lebrasseur, M. Borovanská \& M. Janda. 2016. Identification of microsatellite markers for a worldwide distributed, highly invasive ant species Tapinoma melanocephalum (Hymenoptera: Formicidae). European Journal of Entomology 113:409 414.

Manuscript received 31 August 2016, revised 1 June 2017. 


\section{$2 \mathrm{BHL}$ Biodiversity Heritage Library}

Wawer, Wioletta et al. 2017. "Population structure of the expansive wasp spider (Argiope bruennichi) at the edge of its range." The Journal of arachnology 45(3), 361-369. https://doi.org/10.1636/joa-s-16-056.1.

View This Item Online: https://www.biodiversitylibrary.org/item/274724

DOI: https://doi.org/10.1636/joa-s-16-056.1

Permalink: https://www.biodiversitylibrary.org/partpdf/289920

\section{Holding Institution}

Smithsonian Libraries

\section{Sponsored by}

Biodiversity Heritage Library

\section{Copyright \& Reuse}

Copyright Status: In Copyright. Digitized with the permission of the rights holder

Rights Holder: American Arachnological Society

License: https://creativecommons.org/licenses/by-nc-sa/4.0/

Rights: http://www.biodiversitylibrary.org/permissions/

This document was created from content at the Biodiversity Heritage Library, the world's largest open access digital library for biodiversity literature and archives. Visit BHL at https://www.biodiversitylibrary.org. 